\title{
Landslides in Alaska
}

Alaska Division of Geological \& Geophysical Surveys

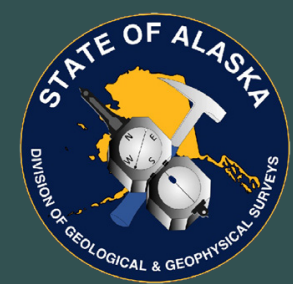

\section{Landslide}

is a catch-all term that refers to mass movement of rock and soil
Landslides cause deaths, injuries, and homelessness every year, and damage or destroy buildings, roads, and other infrastructure. \section{Many regions in Alaska} are especially prone to landslides.

\section{Changing climate in Alaska increases the risk of landslides}

Increases in tsunami-producing landslides in Southeast Alaska can be attributed to retreating glaciers and thawing permafrost. Collapse of hanging glaciers and rock-ice faces is most common in areas with glaciers and steep topography-frequently the same areas that attract tourists. These types of landslides are among the most dangerous to people and infrastructure.

Studies show that changing climatic conditions, like increased rainfall and permafrost degradation, can increase the frequency of fast-moving, catastrophic landslides. Alaska's warming climate has already caused many areas to become unstable. Future warming will increase landslide risk throughout the state, especially in permafrost and glacial regions. At the same time, population growth and the expansion of settlements and lifelines over potentially hazardous areas are increasing the impact of landslides.

\section{Landslide maps help raise} awareness and promote public safety

Very few landslide maps exist for Alaska. Investing in landslide maps helps raise public awareness of landslides and their consequences, and promotes public safety. By providing up-to-date awareness of areas of instability before problems occur, landslide maps save time, money, and lives.

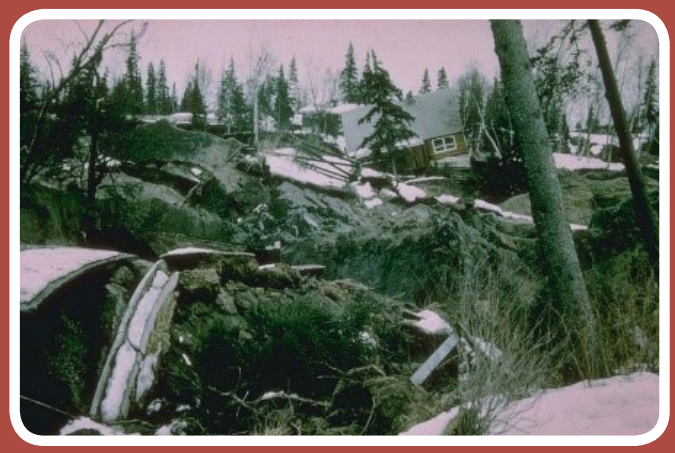

Landslide damage, 1964GreatAlaska Earthquake

Alaska's climate and geology result in landslide trigger

mechanisms such as:

Permafrost degradation

Glacial retreat

Earthquakes

Isostatic rebound

The above trigger mechanisms can cause some unique types of landslides:

Snow-ice-rock avalanches

Frozen debris flows

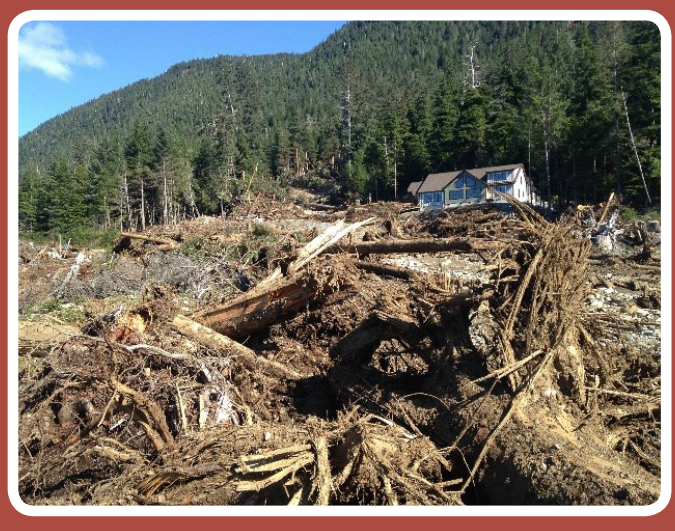

Sitka Debris Flows. On August 18,

2015 , heavy rains resulted in numerous landslides in and around Sitka, Alaska. More than 45 landslides were initiated during this rainfall event. Four debris flows (very water-rich landslides) impacted homes and infrastructure in Sitka, and this one took the lives of three Sitka residents.

Read about other recent Alaska landslides on the back. 


\section{Recent Alaska Landslides}

Alaska Division of Geological \& Geophysical Surveys
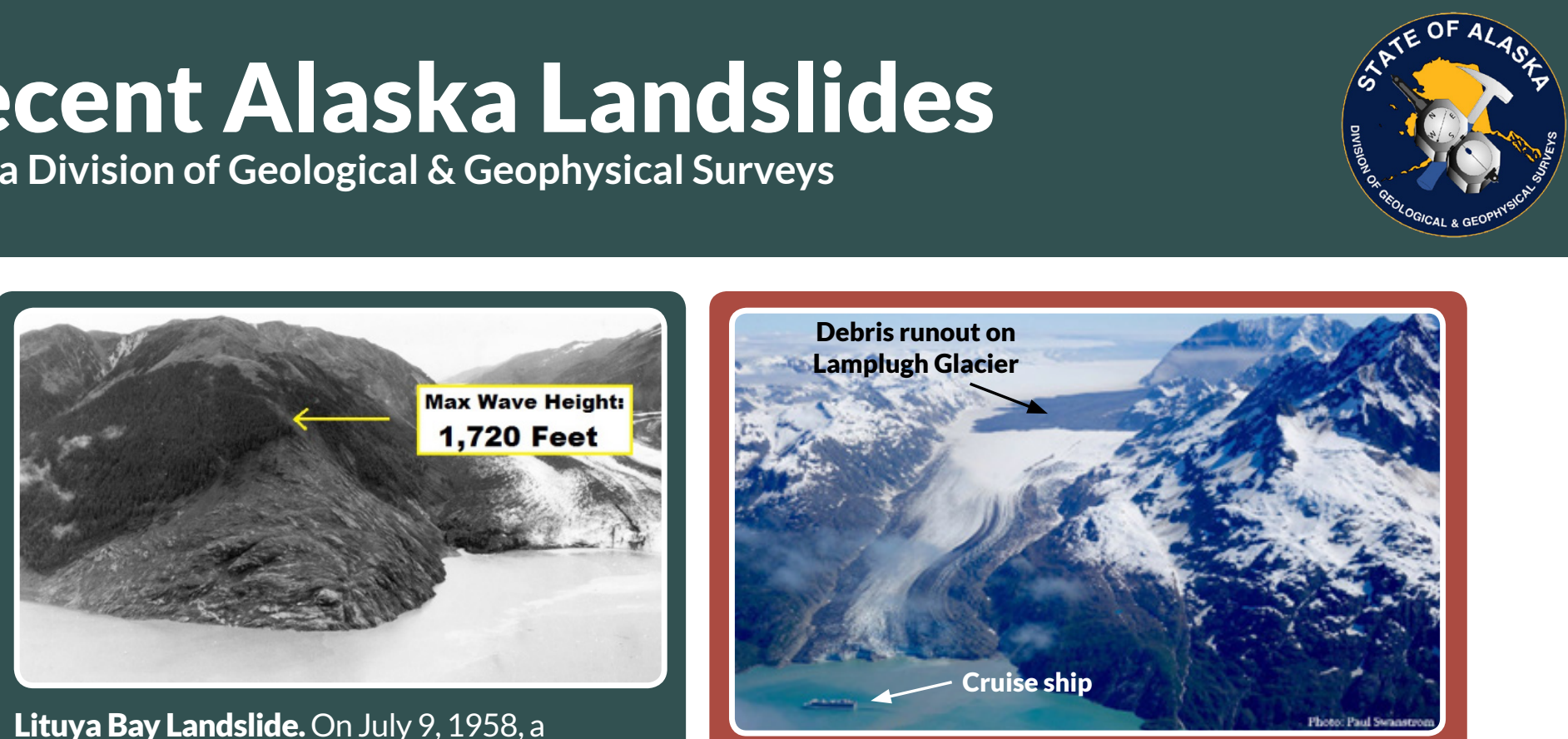

Lituya Bay Landslide. On July 9, 1958, a

magnitude 8 earthquake along the Fairweather

Fault dislodged about 40 million cubic yards

of rock from a mountainside, sending it 3,000

feet downslope into Gilbert Inlet. The wave that followed surged 1,720 feet up a mountain slope and left trimlines along the bay that are still visible today.

Lamplugh Glacier Snow-Ice-Rock Avalanche. On June 28, 2016, a massive landslide crashed onto a glacier in Glacier Bay, Southeast Alaska. More than 100 million tons of rock, snow, and ice slid down a mountainside, sending debris six miles down Lamplugh Glacier. Snow-ice-rock avalanches like this are becoming more common with receding glaciers.

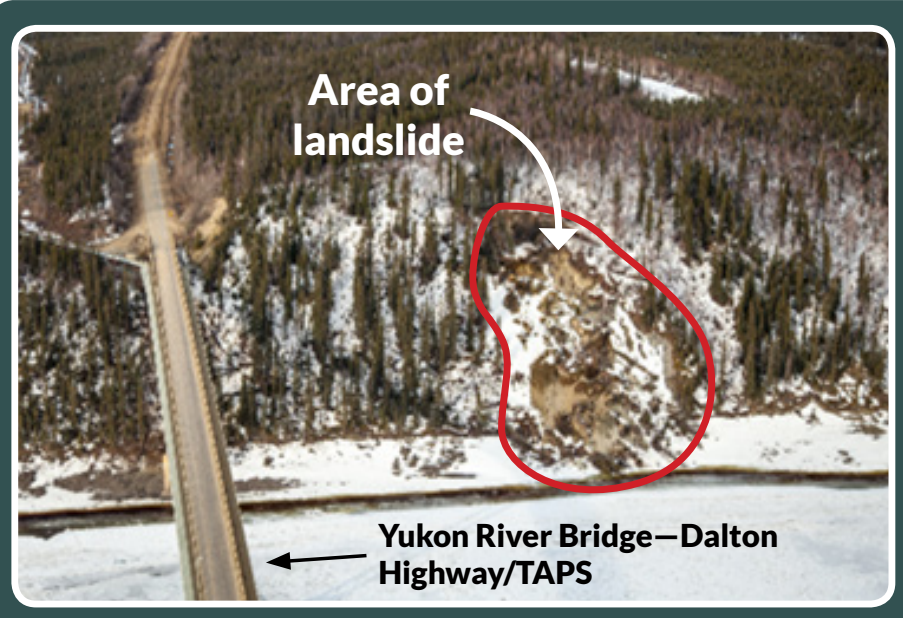

Yukon River Bridge Landslide. In 2012 a landslide occurred approximately 375 feet from the Dalton Highway bridge over the Yukon River. The Dalton Highway and the Trans-Alaska Pipeline System rely on the bridge to connect Fairbanks to the Prudhoe Bay oilfields, ensuring an uninterrupted corridor for the transportation of supplies and personnel. Any compromise to the bridge's integrity could potentially have immediate and severe consequences to the state's economy and environment. Although there was no damage to the bridge foundation, the landslide's close proximity to the bridge raised concerns over additional potential failures.

Icy Bay Landslide. After a period of heavy rains, a mountainside near Tyndall Glacier collapsed on October 17, 2015, dropping 200 million tons of rock into a fjord of Icy Bay. The displaced water generated a wave that denuded vegetation more than 500 feet up on a hillside across from the slide.

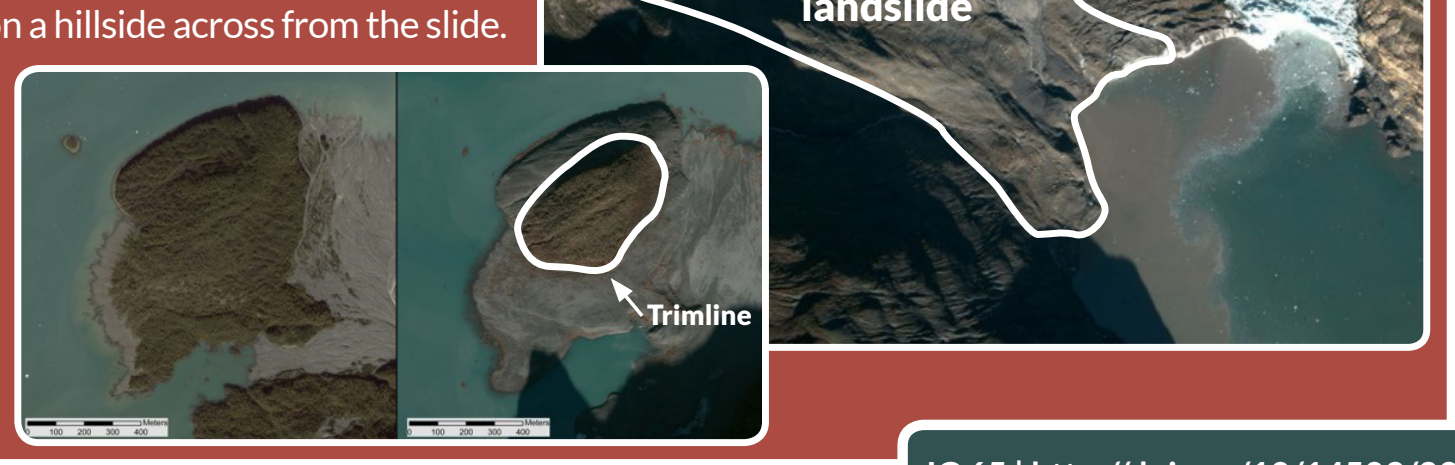

